\title{
Critical Perspective on Agribusiness Supply Chain Management (ASCM) in Developing Nations: What are the Policy and Institutional Lessons for Developing Economies?
}

\author{
Ume Chukwuma $O$ \\ Department of Agricultural Economics \\ University of Nigeria, Nsukka \\ Ihedioha Nice $\mathbf{N}$ \\ Department of Agricultural Economics \\ University of Nigeria, Nsukka \\ Opata Patience I \\ Department of Agricultural Economics \\ University of Nigeria, Nsukka \\ Obiajulu Chukwuchebe U \\ Department of Agricultural Economics \\ University of Nigeria, Nsukka \\ Correspondence to: chukwuma.ume@unn.edu.ng \\ Phone number: 08032533956
}

Received: November 8, 2018

Accepted: November 12, 2018

Online Published: November 17, 2018

\begin{abstract}
This paper seeks to explore and assess literature on Supply chain management. The overarching aim is to derive institutional and policy lessons for the agribusiness sector, especially among the least developed economies. The focus is to better understand the range of supply chain initiatives prevalent in literature and how they fit into the developing nations contexts. Unpacking what supply chain initiatives exist in scholarly publications is relevant since scholarly ideas often shape institutional and policy directions and negotiations in the agricultural sector interventions. Using subjective criteria, sourcing, screening and selection of documents, and conducting qualitative analysis and validation were done. In exploring this discourse, we observe the emergence of a variety of overarching initiatives - development of short food supply chains, supply chain partnership, and supply chain integration. Findings from the study suggest that there is a need for some level of coordination of processes and activities within and between agribusiness firms in the supply chain, in order to build a stronger agribusiness subsector.
\end{abstract}

Keywords: Supply Chain, Integration, Partnership, Rural development, Agribusiness 
Abbreviations: SCM: Supply Chain Management; ASCM: Agribusiness Supply Chain Management 3PLs: Third Party Logistics; ICT: Information and Communication Technology

\section{Introduction}

Agribusiness activities around the world are expanding beyond boarders and redefining the way supply and demand of agricultural and agro-allied products are managed (UNDP, 2013). Today, with the help of Information and Communication Technology (ICT), 3rd Party Logistics (3PLs) and free liberalization, ASCM has the power to improve customer service delivery, reduce preying cost and improve financial position of agribusiness enterprises. As per definition, ASCM is the coordination of the network of activities business from raw-material procurements to manufacturing and distribution of finished goods. The concept of ASCM refers to the activities of procurement to delivery, executed by two or more separate organizations in the agribusiness industry (Folinas, Vlachopoulou, Manthou, \& Manos, 2003).

Recently, there has been a high demand on the agribusiness sector in today's digital economy to spread its enterprise and communicate automatically with its suppliers, customers and trading partners, to take advantage of the ICTs, to participate in emerging supply chain networks, and to energizing their core competencies (Folinas et al., 2003). The forgoing suggests that enterprises with weak or inefficient supply chain strategy will be unable to make its products available at the necessary positions, thereby deterring prompt service delivery and customer satisfaction. In Africa, there is the need to leverage on ASCM to improve agribusiness performance in the continent. Studies dealing with the role of agriculture in economy recovery and growth have helped create a sense of urgency among policy makers to focus on agribusiness as a foundation for thelong-term economic transformation of the continent. A robust and integrated agribusiness supply chain will help the agricultural sector build competitive edge in the global market. One of the reasons the attempt at agricultural development is still crawling in Africa is due to the poor performance ASCM that is the prerequisite for the expected take-off (Adeosun, 2016). The ASCM when fully developed will provide the necessary ladder to move to the phase of industrialization which is synonymous with the phase of rural development (Marsden, Banks, \& Bristow, 2000).

In recent years, research interest agribusiness and food supply chain framework analysis in Africa has risen considerably. This is evidenced by the number of research articles published on this subject matter in recent years (2008 - 2018). This article is grounded in the developing nations of Africa. Agribusiness activities in these nations 
have been slow due to the poor performance of ASCM (UNDP, 2013). Dialogues on Agricultural development within the least developed economies have acknowledged the importance of strengthening collaboration and partnerships in the ASCM and to address the low performance of the 3PLs, as well as to develop an appropriate policy and institutional background to support needs based policy actions (Njoku \& Alexanda, 2015). Robust decision-making processes in the agribusiness sector that are participatory and decentralised will facilitate efficient coordination in ASCM (Ume, 2017). Such processes can present new ideas before policymakers, making policymakers aware of the opinions held by key actors in the sector (Chukwuemeka, Kingsley, \& Ume, 2018). Good ASCM integration framework is essential for the good performance of the agribusiness sector in Africa (UNDP, 2013).

The ASCM within and among agribusiness organizations are often organised separately. If these activities are considered together, integration can become significantly easier (Njoku \& Alexanda, 2015). Since it is no longer suitable to use a standalone SCM framework in the developing countries agribusiness sector (Folinas et al., 2003), integration across key policy areas holds promise (Carys, Waddell, \& Sinclair, 2007), harmonising divergent approaches will align them to reduce vulnerabilities (Ellram \& Cooper, 1990). Integration helps to avoid setbacks and ensures that implementation delivers multiple solutions to agribusiness firms. Indeed, integrating supplychain activities in the agribusiness sector can be well suited to local agribusiness development course.

Several researches on ASCM in Africa are organized around three sets of themes: "ASCM development risk structures", "influence of SCM BY either internal environment or organization of the firm, or by external institutional factors", and "different frameworks for assessing the impact ASCM on the competitive position of agribusiness. To establish the field further, this paper serves three purposes: first was to offer a systematic literature review on ASCM in Africa taking 8 papers published from 2008 to 2016 into account. The main message from the lessons of the last ten years is that countries can overcome their most intractable challenge in agribusiness development if they can bring high-level integration into their ASCM framework, by Establishing supply chain partnerships. The second purpose is to underscore Africa's latecomer benefits. Exponential growth in ICTs and 3PLs is expanding the range of technical knowledge that the continent can marshal for agribusiness transformation. 3) the final objective is to offer policy and institutional lessons for policy makers and industrialists. 


\section{Research design and methods}

It should be pointed out that this article does not attempt to provide a complete inventory of all the issues bothering on ASCM in Africa but only a sample of those that have received a fair amount of attention in literature. Likewise, no effort is made to cover the vast literature on supply chain management by authors whose studies are not grounded in Africa nor focused on the key frameworks and structures necessary for strengthening supply chain networks in the regions. What we hope to do is provide enough examples of these structures to show why they are important for understanding and analysing ASCM problems and devising strategies for solving them.

Systematic literature review approach was employed to thoroughly analyse selected 8 studies covering issues pertaining to SCM in the developing nations, to unpack narratives and implications for the agribusiness subsector. Using subjective criteria, screening and selection of documents, sourcing for documents, and conducting qualitative analysis and validation was done. Summary of article selection criteria is presented on table 1.

In this study, articles on the key themes on SCM from Africa, including those written by non Africans authors were selected and sampled $(n=20)$. Documents that did not meet these criteria were screened out, leaving 12 for further analysis. Documents selected were those targeting key intervention needs in the supply chain management particularly in the developing nations and included published and unpublished publicly available materials. Research gate, Google scholar, and the web of knowledge sources were searched to collate the documents. Triangulation via informal discussions with agribusiness officials were done to further collaborate the discussions. Whilst this review cannot claim to include all related literature, the emerging narratives showed gaps in vital areas across ASCM.

Analysis of literature began by reading all the selected papers in detail, marking sections, phrases, and keywords, and identifying the lessons they communicate in relation to 'supply chain', 'agribusiness', 'integration', 'partnership' and 'Africa', including identifying the range of approaches/strategies implemented or proposed in the papers. Next, the specific initiatives and approaches identified were further analysed within a wider discursive context in which the approaches are situated. This further guided the in-depth discussion which followed a series of questions about whether partnerships and integrations are considered in ASCM in Africa? Are there benefit in for Africa in terms of integrating ICT development and 3PLs in agribusiness supply chain framework? Table 2 shows the findings from the qualitative analysis. 


\section{Results and Discussion}

3.1 What is the range of ASCM initiatives developed/implemented to lubricate the wheel of SCM in the agribusiness subsector?

Africa holds $60 \%$ of the world's uncultivated arable land therefore, remains a strategic continent for the world's agro-food industry (UNDP, 2013)The agricultural sector contributes over 25\% of the regions Gross Domestic Product (GDP) and accounting for more than 60\% towards regional employment (UNDP, 2013). However, $80 \%$ of all farms in most parts of the region are under smallholder production supplying up to $90 \%$ of the food production in some countries (UNDP, 2013).

The emergence of Supply chain development and integration models has been prominent in much ASCM initiative that has been proposed in the last decade. Before then, much attention focused on addressing short food supply chains and their role in rural development. The attention shifted to supply chain integration (including web-based integration) following ever increasing globalization of markets. At the same time, advances in ICT appeared to have forced agribusiness firms in Africa to develop innovative web-based supply chain networks, in order to build their competitiveness and interoperability. The forgoing saw the emergence of a variety of overarching initiatives. The existing initiatives were screened and categorised under these three themes - development of short food supply chains, supply chain partnership, and supply chain integration

\subsection{Development of short food supply chains}

Under the current form of local market conditions in most developed and developing nations, characterised by long, rationally organized and complex industrial chains (Marsden et al., 2000), there is the possibility of a steady and continuous leakage of substantial capital away from the rural areas and the farms. Hence, the need for a shorter food supply chains that will be relevant in bridging the distance between the producers and consumers. This has been the argument of most literature cantered on the development of short food supply chains (Adeosun, 2016; Marsden et al., 2000; Roekel et al., 2018). Short food supply chains, according to Guy, (2000) involves the development of alternative food chains or food networks that reduces the number of times products are handled between production and final delivery to the consumers. The overarching goal is to short circuit irrelevant middlemen while majority of the total value additions are captured by primary producers, the farmers in the rural sectors. 
Key policy and institutional lessons can be derived from this model. First, one critical theme in the short food supply chains discourse is the key role it plays in Rural Development. For instance, a study conducted by Marsden et al., (2000, p.429) using case studies of different short food supply chains in Europe shows that, 1) producers with short food supply chains tends to develop "innovations that go beyond state support". 2) they develop "experiments and innovations" that resists adverse national policies. As noted by Adeosun, (2016), one of the critical risk structures in agribusiness supply chain arises from negative state policies, hence the need to establish supply chain alternatives that will resist such negative state policies. 3)this mode represents a new form of ASC that combine regional and value addition supply of food in a composite form beyond the normal or simple forms. In other words, they add values associated with the commodity themselves. 4) Their study showed that the cross section of short food supply chains studied had encouraging value added profits in terms of farm-level income. These gains were found to be more than what would have been obtained if they had adopted the usual mainstream industrial channels.

Secondly, Okpara (2003) advanced the concept of "Traceability" as an important aspect of the short food supply chain model. Apart from its role in rural development, short food supply chain can also be very important in engendering timely and accurate traceability of commodities in the ASC. This is because in short food supply chains, commodities delivered to final consumers are embedded with information (this can be in the form of printed labels on the packaging or even communicated in person at the point of sale). This model assists the consumer to "confidently make connections and associations with the place/space of production, and, potentially, the values of the people involved and the production methods employed" (Marsden et al., 2000, p.425). This can be related to the current trend in the fruit juice industry in Nigeria. The products Capri-Sun and Capri-Sonne are two different fruit drinks supposed from the same company. Whereas Capri Sun is a brand name owned by Rudlf WILD, a German company, CHI Limited is the exclusive licensee of Capri Sonne under licence of Capri-Sun AG, Zug Switzerland for Nigeria. The information contained in the Packaging of these products makes it easy for the consumers to make purchase decisions in choosing which product they desire based on people involved and the production methods employed. A typical case of short food supply chain is the case of Capri Sonne by CHI Limited. The shortness of the chain gives more gains to the company compared to what it would have been when CHI Limited engaged in the distribution imported Capri Sun, as the total value additions are by CHI Limited. Further, when CHI Limited 
successfully translates their information to the consumers, it allows for product differentiation from more "anonymous products" and to attract a first-class price if the embedded information appeals to consumers.

Marsden et al., (2000) identified 3 types of short food supply: The Face-to-face, Spatial proximity, and Spatially extended. In face -to-face, consumers purchase a commodity directly from the producer. In this case, through personal interactions, authenticity and trust are mediated (Thevenot, 1998). Similar variant of the face-to- face type is the Internet market and on-line trading(See: Folinas et al., 2003). In Spatial proximity, production and marketing are done within a location and the 'local' nature of the product conveyed to the consumers who have personal experience of that region. In Spatially extended, information about the producers and place of production conveyed to consumers who are outside of the region. In general, it is possible for a business to be involved in more than one of these different food supply chains.

\subsection{Integrated Agri-supply chain management}

There are different components of an Agri supply chain. Success and effectiveness IN ASCM entails managing the relationships between the components for an efficient production and supply of products from the farm level to the consumers(Habib, 2014). For effectiveness in ASCM review and empirical studies are replete with key lessons. First, there must be a sound relationship between transportation and warehousing among agribusiness firms (Folinas et al., 2003). This will lead to reduced inventory and ensure quick response to customer requests (Ambe \& Badenhorst-weiss, 2012). Secondly, studies like Folinas et al., (2003) have shown the importance of web-based integration of data and processes in the agribusiness supply chain. Several benefits are derivable from leveraging internet applications. Integrating ICT into SCM will lead to time and cost reduction. Thirdly, integration will help expand markets beyond firms' boundaries thereby increasing sales volume.

Recently, there has been an increase in the level of coordinated supply chains for most agricultural commodities in India (Indian Ministry of Agriculture, 2018). Many developing nations can learn from India’s coordinated supply chain. According to (Agriculture, 2018), Coordinated supply chain will involve strategic dealings among producers, processors, traders, and buyers. The strategy was based on the idea that detailed specifications are provided to all stakeholder on what and how much of the commodity to produce, quality and safety conditions required, the time of 
delivery, etc. This was achieved, according to the ((Indian Ministry of Agriculture, 2018), through web based technology and finance.

Given the short lifetime of many agricultural products, and the seasonality on harvest, there is the need for a collaborative effort in decision-making about planning, procurement, inventory management and distribution. In India for instance, different models are emerging. One of such model that has enhanced ASC is the fruit and vegetable retail outlets. The retail outlets directly purchase produce from the farms through contract arrangements. Collection and grading centres were also established in the rural areas. All the produce is scheduled to move through a central distribution facility located in the rural areas. These facilities have central modern infrastructures such as cold storage, controlled atmosphere chambers, and ripening rooms. According to (Indian Ministry of Agriculture, (2018, p.8), "growers are required to follow certain specifications and are often provided with some inputs and technical advice about agronomic and post-harvest practices".

A terminal market for the fruits and vegetables was also established in different regions. The markets (locally called SAFEL) have the capacity of handling over 1600 metric tons of produce daily and are linked to over two hundred and fifty Farmers and forty Collection Centres. This model presents a typical ASC integration for perishables. It was based on one of India's major agricultural Marketing Act known as the APMR Act. One key advantage of the Integrated Agri-supply chain management typified by the APMR model is that it provides for economies of scale to the small firms in establishing direct linkage between farmers, and other stakeholders such as the processors, exporters, and retailers. Also, the model provided both forward and backward linkages that will engender integrated ASC for different agricultural produce in the country.

\subsection{Establishing supply chain partnerships}

With the substantial rise in partnerships between 3PLs providers, the range of services provided has also increased, however, many agribusiness enterprises in the developing nations are yet to take advantage of these services. This is in spite of the potential benefits of involvement in supply chain partnership. Carys, Waddell, \& Sinclair, (2007) conceptualized partnership in SCM as trading relationship between firms and branded manufacturers of foodstuffs. According to Ellram \& Cooper, (1990), efficient partnership among SCM must go beyond partnership between agribusiness firms to include partnerships between firms 3PLs providers. UNDP, (2013) identified an array of 
pertinent transactional services that 3Pls typically offer to agribusiness firms: operating warehouse functions, big data analytics, sending out shipments, technology (ICT) management, booking freight, asset recovery, and robust reporting. As identified in Ellram \& Cooper, (1990) One of the problems that has hindered collaboration between 3PLs and agribusiness firms, especially in the developing economy is there inability to employ the more strategic services offered by 3PLs. according to Carys et al., (2007) "the majority of clients utilize logistics services such as warehousing and transportation, forgoing the latest developments in supply chain consulting and IT, trade and compliance services".

With the advancements in information and communication technology, agribusiness firms in the developing nations must promote long-term savings by partnering with the more strategic 3PL services. Studies has shown that most firms enjoy cost savings transactions with 3PL services, but that savings begin to go down as the firms fail to innovate over time. According to Ellram \& Cooper (1990) "the prime method to preventing these declines in ROI is to move the 3PL relationship from transactional to strategic".

One important case study which developing firms can engage is the strategic partnership services offered by "Flash Global - A 3PL provider". 3PL such as the Flash Global have the tools and visibility to furnish agribusiness firms with an overview of risk exposure and advise suitable solutions that may be systemic or local. By this, agribusinesses will begin to gain greater insight into hidden costs and the gain advice on how to develop innovative solutions. For instance, Flash Global provides a comprehensive overview to predict labour related disruptions or unexpected natural disasters by analysing risk intelligence- data across the supply chain. Leading agribusiness firms are already exploring these services. Many firms have already employed the use of artificial intelligence or robotics to automate repetitive labour-intensive tasks such as invoicing, purchasing, and accounts payables. Predictive analytics are aiding firms forecast demand, so as to reduce volatility, provide customer convenience, increase asset utilization, and optimized cost.

\section{Conclusion}

Discourses of ASCN serve to articulate the variety of important themes that can serve as lessons in improving supply chains management among agribusiness firms in the developing nations. The analysis presented here illustrates that there are three main initiatives that has dominated food supply chain over the years - Supply chain 
integration, Establishing supply chain partnerships, and Development of short food supply chains. Based on literature review and case studies, idea from this article suggests that there is a need for some level of coordination of processes and activities within and between agribusiness firms in the supply chain. Also, current insights illustrate a deterministic narrative of short food supply chain can induce saving for farmers and hence a tool for rural development. In this light, an inclination towards improving the capacity of farmers in value addition offers a useful direction on how we might improve grass root agribusiness. This idea points to what may constitute parts of an integrative framework's requirements for modeling pathways between local production and agribusiness revolution. It is our contention that since much the take-offs in the agricultural sectors is been driven by a robust agribusiness subsector, building strong supply chain initiatives that will re-enforce or merge the three initiatives that will allow for more convergence will be of significant benefit to the agribusiness sector of most developing economies.

\section{References}

Adeosun, K. P. (2016). Unravelling Risk Structures in Nigeria's Rice Supply Chain : A Review of the Literature, 8(6), 26-34.

Agriculture, M. O. (2018). Supply Chain Management in Agriculture Reading Material. National Institute Of Agricultural Extension Management, Training manual

Ambe, I. M., \& Badenhorst-weiss, J. A. (2012). Supply chain management challenges in the South African public sector, (November). https://doi.org/10.5897/AJBM12.360

Carys, E. S., Waddell, F. N., \& Sinclair, M. A. (2007). The Role of 'Partnership' In Supply Chain Management for Fast-Moving Consumer Goods: a Case Study. International Journal of Logistics Research and Applications, 2(1), https://doi.org/10.1080/13675569908901574

Chukwuemeka, S. U. M. E., Kingsley, O. A., \& Ume, C. (2018). Climate Change Vulnerability Analysis Of Smallholder Farmers in Enugu State Nigeria : Gender Sensitive Approach, 1-6. https://doi.org/10.25081/jaa.2018.v4.3374

Ellram, L. M., \& Cooper, M. C. (1990). Supply Chain Management, Partnership, and the Shipper - Third Party Relationship. The International Journal of Logistics Management, 1(2), 1-10.

Folinas, D., Vlachopoulou, M., Manthou, V., \& Manos, B. (2003). A Web-Based Integration Of Data And Processes In Supply Chain, (July), 143-149.

Guy, C. (2000). Pilot study of local retailer-supplier linkages in two rural areas. Unpublished Report for Tesco Stores Ltd.

Habib, M. (2014). Supply Chain Management ( SCM ): Its Future Implications, (September), 238- 246.

Marsden, T., Banks, J., \& Bristow, G. (2000). Exploring their Role in Rural Development Food Supply Chain Approaches :, 40(4).

Njoku, M. E., \& Alexanda, K. (2015). Effective Supply Chain Management :, 3(12), 90-112. 
Okpara, L. U. (2003). Traceability in agriculture and food supply chain : A review of basic concepts, technological implications , and future prospects. Food, Agriculture \& Environment, 1(1), 101-106.

Roekel, J. Van, Kopicki, R., J.E, C., \& Boselie, D. M. (2018). Building Agri Supply Chains : Issues and Guidelines. Agri Chain Competence Center.

Thevenot, L. (1998). Innovating in 'qualified' markets: Quality, norms and conventions. In Paper presented at Systems and Trajectories of Innovation Conference, Institute of International Studies, University of California, Berkeley.

Ume, C. (2017). Critical Perspective on Climate Change Adaptation among Farmers in Developing Nations : Unpacking Divergent Approaches. Mod Concep Dev Agrono, 2(1), 1-6.

UNDP. (2013). Nigerian Agribusiness Supplier Development Programme. Nigerian Agribusiness Supplier Development Programme.

\section{Appendices}

\section{List of Tables}

Table 1: Summary of article selection criteria

The article focused on supply chain management in the developing nation context

The research was conducted within the last decade

The word "Africa" or "rural development" was mentioned either in the title, abstract or body of the article, apart from the reference list

Employed a clear research methodology and suggested clear approach agribusiness firms have or should employ (articles not showing a clear research methodology and adaptation approach were excluded)

Table 2: Findings from the qualitative analysis

\begin{tabular}{|c|c|c|c|}
\hline $\begin{array}{l}\text { Initiative contained } \\
\text { in sampled document }\end{array}$ & $\begin{array}{l}\text { Overarching goal and the associated } \\
\text { thematic area(s) }\end{array}$ & $\begin{array}{l}\text { Theme of the } \\
\text { initiative }\end{array}$ & Source \\
\hline $\begin{array}{l}\text { Supply chain } \\
\text { integration guiding } \\
\text { model for the } \\
\text { manufacturing industry }\end{array}$ & $\begin{array}{l}\text { It shows the flow of a five stage process } \\
\text { which starts from having sound knowledge } \\
\text { of the company's current supply chain } \\
\text { operations to the critical examination of the } \\
\text { supply chain integration level in the } \\
\text { company; establishing the external } \\
\text { challenges thereof, then putting in place a } \\
\text { successful Supply chain integrated } \\
\text { operations in practice that will go a long } \\
\text { way in reducing the lead time and also } \\
\text { reduce the cost of production }\end{array}$ & $\begin{array}{l}\text { Supply chain } \\
\text { integration }\end{array}$ & $\begin{array}{l}\text { (Njoku \& } \\
\text { Alexanda, 2015) }\end{array}$ \\
\hline $\begin{array}{l}\text { Agribusiness } \\
\text { Supplier } \\
\text { Development } \\
\text { Programme. }\end{array}$ & $\begin{array}{l}\text { Its ambition is to work on } \\
\text { practical knowledge for market } \\
\text { development through } \\
\text { collaborating more directly with } \\
\text { the private sector in order to have }\end{array}$ & $\begin{array}{l}\text { Establishing } \\
\text { supply chain } \\
\text { partnerships }\end{array}$ & (UNDP, 2013) \\
\hline
\end{tabular}




\begin{tabular}{|c|c|c|c|}
\hline & a larger impact & & \\
\hline $\begin{array}{l}\text { The emergence of } \\
\text { 'short food supply } \\
\text { chains': Exploring } \\
\text { their Role in Rural } \\
\text { Development }\end{array}$ & $\begin{array}{l}\text { It offers potential to develop } \\
\text { supply chains that can potentially } \\
\text { 'short-circuit' the long, complex and } \\
\text { rationally organized industrial chains } \\
\text { within which a decreasing proportion of } \\
\text { total added value in food production is } \\
\text { captured by primary producers. }\end{array}$ & $\begin{array}{l}\text { Development of } \\
\text { short food supply } \\
\text { chains }\end{array}$ & $\begin{array}{l}\text { (Marsden et al., } \\
\text { 2000) }\end{array}$ \\
\hline $\begin{array}{l}\text { technological } \\
\text { challenges in } \\
\text { implementing } \\
\text { traceable agricultural } \\
\text { supply chains }\end{array}$ & $\begin{array}{l}\text { Development of appropriate measurement } \\
\text { tools for food product labeling and } \\
\text { identification, activity/process } \\
\text { characterization, information systems for } \\
\text { data capture, analysis, storage and } \\
\text { communication, and the integration of the } \\
\text { overall traceable supply chain are essential } \\
\text { for success }\end{array}$ & $\begin{array}{l}\text { Development of } \\
\text { short food supply } \\
\text { chains }\end{array}$ & (Okpara, 2003) \\
\hline $\begin{array}{l}\text { E-partnerships of } \\
\text { agribusiness supply } \\
\text { chain to function in } \\
\text { the agribusiness } \\
\text { sector }\end{array}$ & $\begin{array}{l}\text { In order to enable organizations } \\
\text { to set up and manage reliably ASC } \\
\text { networks, an Internet-based application is } \\
\text { developed which aims to model and } \\
\text { integrate dynamically and collaboratively } \\
\text { business } \\
\text { processes and agribusiness data }\end{array}$ & $\begin{array}{l}\text { Establishing } \\
\text { supply chain } \\
\text { partnerships }\end{array}$ & $\begin{array}{l}\text { (Folinas et al., } \\
2003 \text { ) }\end{array}$ \\
\hline $\begin{array}{l}\text { Developing chain } \\
\text { strategy and } \\
\text { organization }\end{array}$ & $\begin{array}{l}\text { This paper draws on the experience of the } \\
\text { Agri-Chain Competence Center to discuss } \\
\text { the critical issues and step-by-step actions } \\
\text { necessary to stimulate and support the } \\
\text { emergence of supply chains in developing } \\
\text { countries }\end{array}$ & $\begin{array}{l}\text { Supply chain } \\
\text { integration }\end{array}$ & $\begin{array}{l}\text { (Roekel, Kopicki, } \\
\text { J.E, \& Boselie, } \\
\text { 2018) }\end{array}$ \\
\hline $\begin{array}{l}\text { Risk management } \\
\text { strategies in various } \\
\text { supply chain levels }\end{array}$ & $\begin{array}{l}\text { what contextual risks (production, } \\
\text { processing and storage risks) are important } \\
\text { in describing output variation for different } \\
\text { actors and national output over the years }\end{array}$ & $\begin{array}{l}\text { Development of } \\
\text { short food supply } \\
\text { chains. }\end{array}$ & (Adeosun, 2016) \\
\hline $\begin{array}{l}\text { potential benefits and } \\
\text { risks of involvement } \\
\text { in supply chain } \\
\text { partnership }\end{array}$ & $\begin{array}{l}\text { The paper begins with an } \\
\text { overview of some of the forces } \\
\text { that have shaped supply chain } \\
\text { management and partnership relationships. }\end{array}$ & $\begin{array}{l}\text { Establishing } \\
\text { supply chain } \\
\text { partnerships }\end{array}$ & $\begin{array}{l}\text { (Ellram \& } \\
\text { Cooper, 1990) }\end{array}$ \\
\hline
\end{tabular}

\section{Copyrights}

Copyright for this article is retained by the author(s), with first publication rights granted to the journal. This is an open-access article distributed under the terms and conditions of the Creative Commons Attribution license (http://creativecommons.org/licenses/by/4.0/). 